\title{
Study on the Investment Feasibility of the Fishing Boat Considering the Local Wisdom
}

\author{
Syamsul Alam Muchlis ${ }^{\mathrm{a}}$, Suandar Baso ${ }^{\mathrm{b}, *}$, Sitti Chairunnisa ${ }^{\mathrm{c}}$ \\ aDepartment of Naval Architecture, Engineering Faculty, Hasanuddin, Gowa, Indonesia. Email: alankngejork6@mail.com \\ b Department of Naval Architecture, Engineering Faculty, Hasanuddin, Gowa, Indonesia. Email: s.baso@eng.unhas.ac.id \\ 'Department of Naval Architecture, Engineering Faculty, Hasanuddin, Gowa, Indonesia. Email: andi.chairunnisa@yahoo.co.id
}

\begin{abstract}
Indonesia Government, the Ministry of Maritime Affairs and Fisheries, is holding the procurement assistance program for the fishing boat with size from 5 to 30 gross tonnage (GT). In order to succeed in this program, a comprehensive study on a fishing boat is emphasized to be carried out continuously, and then the local wisdom aspect should be considered. This study aims to determine the feasibility of the investment of the fishing boats with the sizes into 12,21, and 29 GT taking into account the aspect of the local wisdom in the case of Sinjai Regency, South Sulawesi Province, and to determine the weight of local wisdom for the investment of a fishing boat. The investment feasibility was analyzed using the Net Present Value (NPV) and Internal Rate of Return (IRR). In the present results, the three sizes of the fishing boat 12, 21, and 29 GT in Sinjai Regency have met the finacial feasibility. Also, these are suitable sizes to support the fishermen's welfare in Sinjai Regency. For the projection within ten years, the NPV and IRR are for the fishing boat size of 12 GT approximately 823 million rupiahs and 77\% respectively, 998 million rupiahs and 54\% for 21 GT as well as 979 million rupiahs and $38 \%$ for 29 GT. The weight of the local wisdom aspect in the investment of fishing boat is an average of $81.67 \%$, wherein the local wisdom aspect includes the boat hull building, fishing equipment, and labor cost. Also, the weight of the local wisdom aspect for ship operation is an average of $62 \%$, where the local wisdom aspect includes fish recording, maintenance, fish aggregating devices (FADs), and crew salary. For overall, the weight of the local wisdom aspect on the fishing boat building and operation cost are an average of $71.83 \%$.
\end{abstract}

Keywords: Fishing boat; investment feasibility; internal rate of return; local wisdom; net present value

\section{Introduction}

Generally, a fishing boat has a wide variety of body forms around the world. The variety of body forms of fishing boats takes into account several aspects such as safety, performance in operation, ease of operation, etc.

The innovation of fishing boat design has been carried out widely. However, the consideration of traditional aspects has been involved in fishing boat design and building by several countries including Indonesia. In Indonesia, the traditional aspect is called traditional content or local wisdom. And the fishing boat is a traditional boat.

Traditional boat design can be improved in order to improve safety and performance, and it is still accepted by a local fisherman after the improvement. The improvement of the traditional fishing boat construction was proposed with model validation [1]. The fishing boat was designed based on local wisdom in Southeast

${ }^{\star}$ Corresponding author. Tel.: +62-852-5562-5397

Jalan Poros Malino km. 6, Bontomarannu, Gowa

Sulawesi Selatan, Indonesia, 92171
Sulawesi Fishermen [2]. The optimization method of the fishing boat design taking into account local wisdom was proposed [3].

However, the improvement of fishing boat design and building taking into account traditional content affect production cost as well as investment costs. Therefore, the effects must be considered by the shipowner.

Moreover, the investment cost of a fishing boat must be analyzed properly in order to make a business strategy. Correspondingly, financial feasibility has been studied widely by some researchers. Then, the study of the financial feasibility can be a reference for a businessman or other institution. The feasibility of the pole and line fishery was studied in order to compare the level of financial feasibility and determine the level of difference between pole and line fishing businesses [4]. The financial feasibility of the wooden fishing boat in Panggungrejo Subdistrict, Pasuruan, was analyzed and the result fulfills the feasibility value index [5]. The important factors affecting the investment of fishing boats were considered such as vessel age and size, future revenues, operating costs, stock status of the main target species, and the impact of management measures and total fleet size [6]. 
On the other hand, the financial feasibility for the business of fishing boat rental was analysed [7]. However, most studies on fishing boat investment, especially traditional boats, do not reveal the effect of the factors of traditional content on investment costs. Consequently, the influence of the traditional content factor can become large or small, nevertheless, this must be considered to decide properly an investment in fishing boats.

Based on the previous explanation, the value of the traditional content or local wisdom factor on the investment feasibility has been investigated in this present study. Through the Indonesian Government, the Ministry of Marine Affairs and Fisheries is holding the assistance program of fishery ship procurement for fishing boat size GT 5 to GT 30. Therefore, the cost components of fishing boat investment considering the local wisdom or traditional content for the boat size 5 to GT 30 GT have been analyzed. The study has been subjected to a fishing boat in Sinjai Regency, South Sulawesi, Indonesia.

The area of the Sinjai Regency consists of land and island. Correspondingly, Sinjai can be considered as one of the regencies in South Sulawesi that has fishery potential. The Sinjai Regency has a coastline length of approximately $28 \mathrm{~km}$ with the circumference of the island. Therefore, Sinjai Regency has a possibility for business development in the marine and fisheries sectors.

\section{Methodology}

The population of the fishing boats was targeted at the location of Lappa Fishing Port (PPI), Sinjai Regency, South Sulawesi Province.

Regarding the data related to the investment feasibility level of fishing vessels, they were collected directly by conducting observation interview, and questionnaire at Lappa Fishing Port (PPI). On observation, the data were collected such as the main particulars and gross tonnages of fishing boats, kinds of fish, the fishing rate per year, and ship operations per year. For the interviews step, the number of fishing boats, potential fish, and a number of fish catches were collected from fishermen, ship owners, and agencies. Also, in this step, the supporting data were needed such as the number of the crew member, time and length of operation, investment cost component, operational cost (fuel oil, lubricating oil, fresh water, and administrative, crew, and other costs), ship repair cost, and ship maintenance cost. Also, the references subjected to the feasibility of the fishing boat investment considering the local wisdom were collected through internet media.

In this present study, the fishing boat sizes are focused on 12 GT, 21 GT, and 29 GT. The population of these fishing boat sizes is large in Sinjai Regency, and then they can be an illustration of the procurement assistance program for the fishing boat 5 to 30 GT held by the Ministry of Maritime Affairs and Fisheries, Indonesia Government. The main particulars and engine of the fishing boats $12 \mathrm{GT}, 21 \mathrm{GT}$, and $29 \mathrm{GT}$ are shown in Table 1.

The local wisdom aspect involved in the fishing boat building cost and operation cost is identified by observation and interview. Then, the weight of the local wisdom is defined by the cost components that are involved in the total cost component divided by the total cost component of the fishing boat building cost and operation cost.

The feasibility of a fishing boat investment is considered based on the financial parameters of Net Present Value (NPV) and Internal Rate of Return (IRR). The followings are the formulas of NPV and IRR [8]. The NPV can be obtained by using the formula as follow:

$$
\begin{aligned}
& N P V=\left(\sum_{t=0}^{n} \frac{N e t \text { cash flow }}{(1+d f)^{t}}\right) \\
& \text { - Initial investment }
\end{aligned}
$$

where $t$ is time in year, $n$ is the number of time period, and $d f$ is the discount factor.

The discount factor $d f$ can be obtaine as follow:

$d f=\sum_{t=0}^{n} \frac{1}{\left(1 *(1+r)^{t}\right)}$

where $r$ is the discount rate.

Then, the IRR can be obtained by using the formula as follow:

$$
\begin{aligned}
0=N P V= & \left(\sum_{t=0}^{n} \frac{\text { Net cash flow }}{(1+d f)^{t}}\right) \\
& - \text { Initial investment }
\end{aligned}
$$

The return of the investment cost Bpi can be obtained as follow:

$$
B p i=\frac{\text { Net cash flow }}{\sum_{t=1}^{n}\left(\frac{1}{1+d f}\right)^{t}}
$$

\section{Results and Discussion}

\subsection{The total investment cost of fishing boat building}

Here, the investment cost of a fishing boat building consists of several components wherein it includes several

\begin{tabular}{|c|c|c|c|c|c|}
\hline \multirow{2}{*}{ No } & \multirow{2}{*}{ Description } & \multirow{2}{*}{ Unit } & \multicolumn{3}{|c|}{ Ship Size } \\
\hline & & & 12 GT & $21 \mathrm{GT}$ & 29 GT \\
\hline \multirow[t]{5}{*}{1} & Main particulars & & & & \\
\hline & $\begin{array}{l}\text { a. Length overall } \\
\text { (Loa) }\end{array}$ & $\mathrm{m}$ & 14.90 & 19.80 & 20.35 \\
\hline & $\begin{array}{l}\text { b. Length } \\
\text { between } \\
\text { perpendiculars } \\
\text { (Lbp) }\end{array}$ & $\mathrm{m}$ & 11.52 & 15.62 & 16.69 \\
\hline & c. Width (B) & $\mathrm{m}$ & 3.05 & 3.9 & 4.1 \\
\hline & d. Height $(\mathrm{H})$ & $\mathrm{m}$ & 1.40 & 1.2 & 1.9 \\
\hline \multirow[t]{3}{*}{2} & Main engine & & & & \\
\hline & a. Number & Unit & 1 & 2 & 2 \\
\hline & b. Power & $\mathrm{HP}$ & 30 & 30 & 30 \\
\hline \multirow[t]{3}{*}{3} & Auxiliary engine & & & & \\
\hline & a. Number & Unit & 1 & 1 & 1 \\
\hline & b. Power & $\mathrm{HP}$ & 30 & 30 & 30 \\
\hline
\end{tabular}
local wisdom aspects that are involved. The investment component and its cost for each fishing boat size are shown in Table 2.

Table 1. Main particulars and engine power of the fishing boats 
Table 2. Total investment cost of the fishing boat building

\begin{tabular}{|c|c|c|c|c|}
\hline \multirow{2}{*}{ No } & \multirow{2}{*}{$\begin{array}{l}\text { Investment } \\
\text { Component }\end{array}$} & \multicolumn{3}{|c|}{ Investment Cost (Rupiah/Rp) } \\
\hline & & 12 GT & $21 \mathrm{GT}$ & 29 GT \\
\hline 1 & $\begin{array}{l}\text { Hull building } \\
\text { and labor }\end{array}$ & 115.000 .000 & 200.000 .000 & 320.000 .000 \\
\hline 2 & Ship engine & 21.000 .000 & 51.000 .000 & 60.000 .000 \\
\hline 3 & $\begin{array}{l}\text { Fishing } \\
\text { equipment }\end{array}$ & 9.000 .000 & 12.000 .000 & 13.000 .000 \\
\hline 4 & $\begin{array}{l}\text { Required } \\
\text { documents }\end{array}$ & 5.000 .000 & 7.000 .000 & 7.000 .000 \\
\hline & Total & 150.000 .000 & 270.000 .000 & 400.000 .000 \\
\hline
\end{tabular}

Table 3. The results of the analysis of the cost of investment return

\begin{tabular}{lccc}
\hline \multicolumn{1}{c}{ Description } & 12 GT & 21 GT & 29 GT \\
\hline $\begin{array}{l}\text { Total investment } \\
\text { Rupiah) }\end{array}$ & 150.000 .000 & 270.000 .000 & 400.000 .000 \\
$\begin{array}{l}\text { Interest rate (\%) } \\
\begin{array}{l}\text { Returned costs } \\
\text { (Rupiah) }\end{array}\end{array}$ & 6 & 6 & 6 \\
$\begin{array}{l}\text { Total returned cost } \\
\text { (Rupiah) }\end{array}$ & 20.380 .194 & 36.684 .349 & 54.347 .183 \\
\hline
\end{tabular}

Correspondingly, for the investment cost, it is considered to become feasible wherein it can be returned within the age of fishing boat which is approximately ten years. By using the formula of the breakeven point, the returned cost for each fishing boat size within ten years with the interest rate of $6 \%$ is shown in Table 3. The returned cost based on the cash flow is Rp. 20.380.194 for 12 GT, Rp. 36.684.349 for 21 GT, and Rp. 54.347.183 for 29 GT. It is obtained by using the integration of the discount rate in ten years.

\subsection{Fishing boat operation pattern}

The fishing boats sometimes operate outside fishing ground in the sea area of Sinjai's authority such as Jampea, Lombok, and Kupang as shown in Fig.1. Those fishing grounds are nearly the ports of Lombok and Kupang. Therefore, the operation length of the fishing boat is needed for about nine months or called one season.

Furthermore, the round-trip times for Sinjai-Jampea, Sinjai-Kupang, and Sinjai-Lombok as shown in Fig. 1 are considered to determine the operating frequency. Referring to the questionnaire results, the cycle time for the fishing activity includes the times of departure preparation, a port of origin-destination, rest before going to the fishing ground, destination port to the fishing ground, fishing operation, fishing ground to destination port, interval time (due to unloading, fishing sale, and preparation before going to origin port), and destination port to origin port. Based on the cycle time for the fishing activity, the operation frequency within a year for each size of the fishing boat was obtained as shown in Table 4 .

Table 4. The frequency of fishing activity per year

\begin{tabular}{cccc}
\hline No & Route & $\begin{array}{c}\text { Number of operating } \\
\text { days per year }\end{array}$ & $\begin{array}{c}\text { Activity } \\
\text { frequency }\end{array}$ \\
\hline 1 & Sinjai - Jampea & 335 & 23 \\
2 & Sinjai - Kupang & 305 & 14 \\
3 & Sinjai - Lombok & 305 & 15 \\
\hline
\end{tabular}

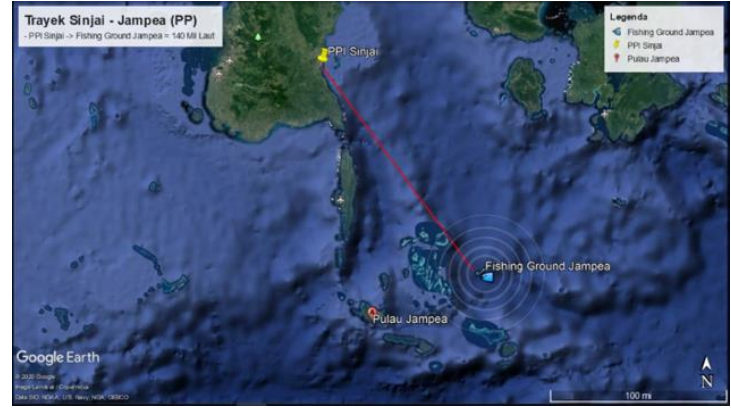

(a)

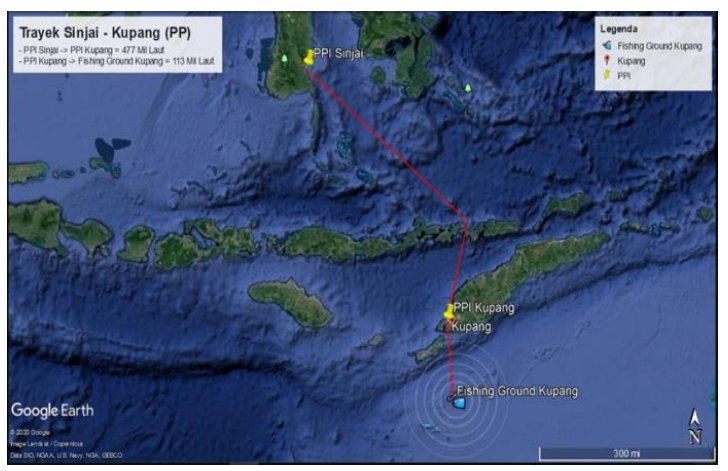

(b)

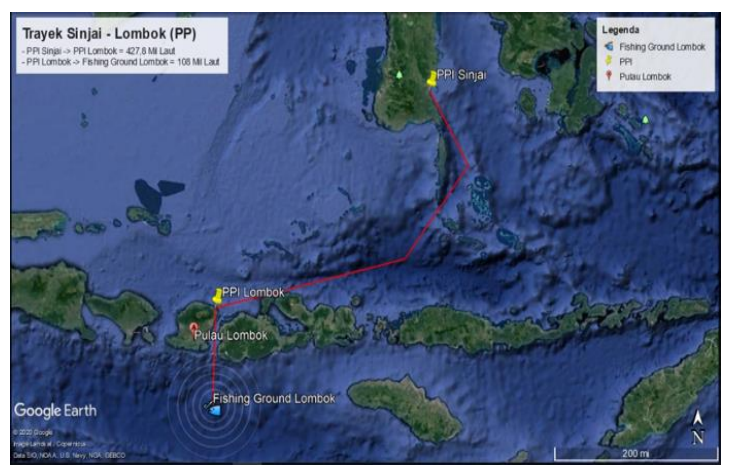

(c)

Figure 1. (a) Round-trip operational pattern for the Sinjai-Jampea route;

(b) pattern for the Sinjai-Kupang route; (c) pattern for the SinjaiLombok route

\subsection{The operation cost of the fishing boat}

The annual operation cost of the fishing boat was identified and analyzed as shown in Table 5. Also, the income and expenses costs are shown in Table 5. The expenses cost includes profit-sharing register and operation permit given by the Regional Revenue Office (called Dispenda). Then, the profit-sharing register and operation permits are defined by $10 \%$ and $3 \%$ of the fish catch seller, respectively. The gross income is defined by the fish catch seller minus the expensive costs. Then, the annual net income is defined by the gross income minus the operation cost. 
Table 5. The structure of annual operation, income, and expense costs of the fishing boat

\begin{tabular}{lccc}
\hline \multirow{2}{*}{ Description } & \multicolumn{3}{c}{ Amount (Rp) } \\
\cline { 2 - 4 } & 12 GT & 21 GT & 29 GT \\
\hline Operation cost & & & \\
Operating & 42.062 .400 & 39.664 .830 & 39.473 .646 \\
machinery (OM) & & & \\
Ice box (IB) & 24.541 .000 & 23.100 .000 & 33.000 .000 \\
Fresh water (FW) & 1.725 .000 & 1.050 .000 & 265.000 \\
Provisions (P) & 92.000 .000 & 56.000 .000 & 157.500 .000 \\
Other services (OS) & 1.150 .000 & 700.000 & 750.000 \\
FADs & 500.000 & 500.000 & 500.000 \\
Maintenance (M) & 5.000 .000 & 10.000 .000 & 15.000000 \\
Total operation cost & 166.978 .400 & 131.014 .830 & 248.848 .640 \\
Income and expense & & & \\
cost & & & \\
Fish catch seller & 438.900 .000 & 589.460 .000 & 743.680 .000 \\
Operation permit & 13.167 .000 & 17.683 .800 & 22.310 .400 \\
3\% & & & \\
Profit sharing & 43.890 .000 & 58.946 .000 & 74.368 .000 \\
register 10\% & & & \\
Gross income & 381.843 .000 & 512.830 .200 & 647.001 .600 \\
Total net income & 214.864 .600 & 381.815 .370 & 398.152 .960 \\
\hline
\end{tabular}

\subsection{Profit sharing scheme based on local wisdom}

The scheme of the production sharing had been determined by the government by issuing Law of the Republic of Indonesia Number 16 of 1964 [8], however, the production or profit-sharing in Sinjai Regency has been considered as the local scheme which involves the aspect of the local wisdom. This local scheme of the income sharing is based on the number adjusted to crew members, after equal distribution, each ship owner, crew member, the registrar has a different share, for instance, a fishing boat has a crew number of seventh people, therefore, the income consists of 17 points (sharing factor). These points are shared with the skippers for three points, crew members for six points, and shipowner for eight points. In the income structure, the total net income and sharing fee for each ship size are shown in Table 6. The total net income for the fishing boats $12 \mathrm{GT}, 21 \mathrm{GT}$, and 29 GT are Rp. 214.864.600, Rp. 381.815.370, and Rp. 398.152 .370 respectively.

Table 6. The structure of income based on local scheme

\begin{tabular}{|c|c|c|c|c|}
\hline \multirow{2}{*}{ No } & \multirow{2}{*}{ Description } & \multicolumn{3}{|c|}{ Fishing boat size } \\
\hline & & $12 \mathrm{GT}$ & $21 \mathrm{GT}$ & $29 \mathrm{GT}$ \\
\hline 1 & $\begin{array}{l}\text { Total net } \\
\text { income (Rp) }\end{array}$ & 214.864 .600 & 381.815 .370 & 398.152 .954 \\
\hline 2 & $\begin{array}{l}\text { Sharing } \\
\text { factor }\end{array}$ & 13 & 17 & 17 \\
\hline 3 & $\begin{array}{l}\text { Number of } \\
\text { crew }\end{array}$ & 4 & 7 & 7 \\
\hline 4 & $\begin{array}{l}\text { Net basic } \\
\text { income (Rp) }\end{array}$ & 16.528 .046 & 22.459 .728 & 23.420 .762 \\
\hline 5 & $\begin{array}{l}\text { Ship's master } \\
\text { sharing fee } \\
\text { (Rp) }\end{array}$ & 49.584 .138 & 67.379 .183 & 70.262 .286 \\
\hline 6 & $\begin{array}{l}\text { Crew sharing } \\
\text { fee }(R p)\end{array}$ & 33.056 .092 & 134.758 .366 & 140.524 .572 \\
\hline 7 & $\begin{array}{l}\text { Owner } \\
\text { sharing fee } \\
(\mathrm{Rp})\end{array}$ & 132.224 .369 & 179.677 .821 & 187.366 .096 \\
\hline
\end{tabular}

Table 7. Annual net income after sharing fee

\begin{tabular}{lccc}
\hline \multirow{2}{*}{\multicolumn{1}{c}{ Description }} & \multicolumn{3}{c}{ Amount (Rp) } \\
\cline { 2 - 4 } & $12 \mathrm{GT}$ & $21 \mathrm{GT}$ & $29 \mathrm{GT}$ \\
\hline Operation cost & 166.978 .400 & 131.014 .830 & 248.848 .646 \\
Catch sale & 438.900 .000 & 589.460 .000 & 743.680 .000 \\
Gross income & 381.843 .000 & 512.830 .200 & 647.001 .600 \\
Net total income & 214.864 .600 & 381.815 .730 & 398.152 .954 \\
$\begin{array}{l}\text { Sharing fee (master } \\
\text { and crew) }\end{array}$ & 86.640 .230 & 202.137 .549 & 210.786 .858 \\
$\begin{array}{l}\text { Net income (after } \\
\text { sharing fee) }\end{array}$ & 132.224 .369 & 179.677 .821 & 187.366 .096 \\
\hline
\end{tabular}

By using the sharing factor, shipowner based on the fishing boat size $12 \mathrm{GT}, 21 \mathrm{GT}$, and $29 \mathrm{GT}$ gains the income of Rp. 132.224.369, Rp. 179.677.821, and Rp. 187.366.096, respectively. These ownership incomes will be used to analyze investment feasibility for those kinds of fishing boats following.

Based on Table 6, after the deduction of operational costs and income sharing, the net profit a year is shown in Table 7.

\subsection{The weight of local wisdom on fishing boat investment}

In order to determine the weight of local wisdom on the investment of the fishing boat, the shipbuilding costs and ship operation costs were broken down into the component costs that implicitly involve the local wisdom aspects. Then, the interview and questionnaire were conducted and addressed to the ship owners to understand the local wisdom aspects of the investment cost. The cost components of the shipbuilding investment for each fishing boat size are shown in Fig. 2. Moreover, the weight of the local wisdom aspect involved in the shipbuilding investment for each fishing boat size is shown in Fig. 3.

Based on Fig. 2, the cost component of the boat's hull is greater than other cost components on the shipbuilding investment. The increase of the boat size impacts significantly on the increase of the boat hull cost. Here, the size of the fishing boat 29 GT is a higher shipbuilding investment than other sizes. For the weight of the local wisdom involved in the shipbuilding cost, the boat's hull and fishing gear costs are contributed implicitly higher weight in the shipbuilding cost. Therefore, the weight of the local wisdom involved in the shipbuilding cost for the fishing boat sizes of 12 GT, 21 GT, and 29 GT are approximately $83 \%, 79 \%$, and $83 \%$ respectively. The high weight of the involvement of local wisdom aspects in the fishing boat building is contributed by the hull form including bow shape, type of fishing gear called Penongkol, room layout, and steering system. The form of a fishing boat is generated from the geometry of the local fishing boat, and the room layout is based on the custom of local fishermen. Moreover, the fishing boat was made of wood material, and then it was constructed by using the hereditary tradition. By the high weight, this means that the investment of the fishing boat building is significantly influenced by the local wisdom aspects. Merely, the cost of required documents for the fishing boat and machinery have not a contribution to the local wisdom. 


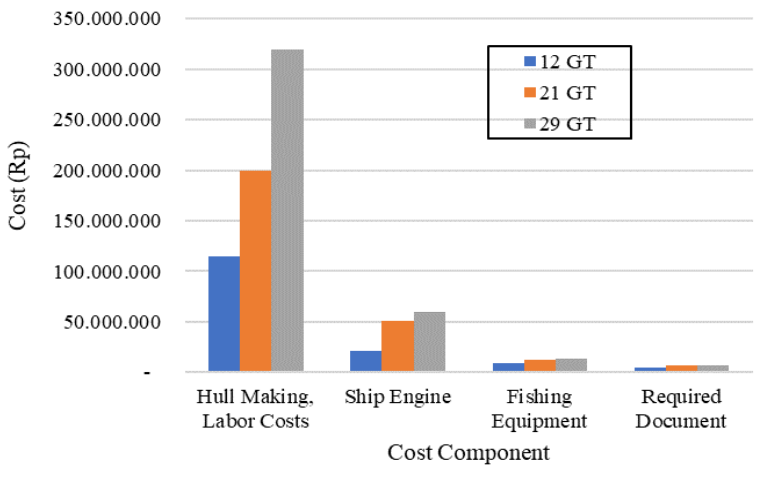

Figure 2. The cost component and its cost of fishing boat building

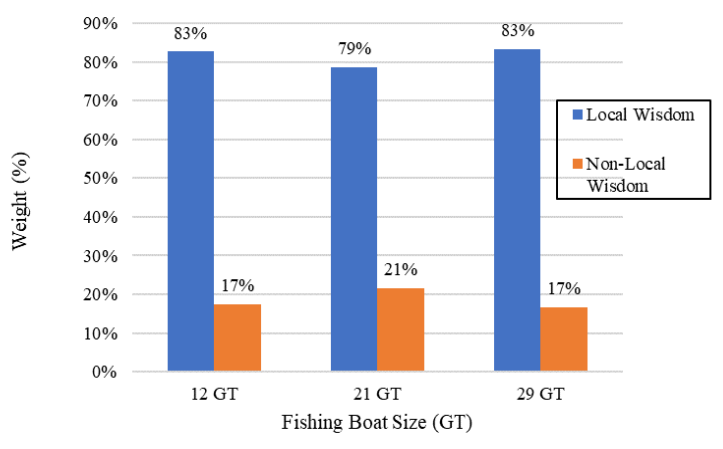

Figure 3. The weight of the of local wisdom on the fishing boat building

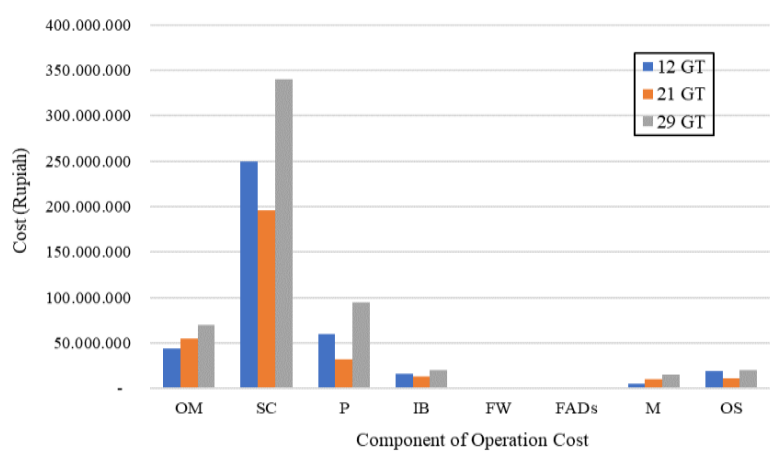

Figure 4. Operation cost of the fishing boat

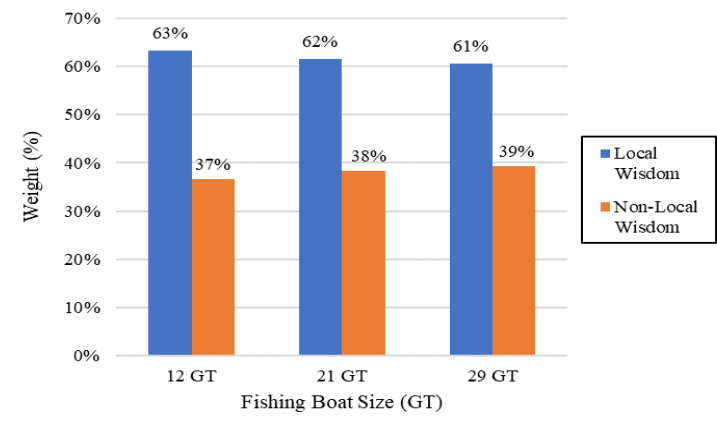

Figure 5. The weight of the of local wisdom on the operation cost

On the other hand, the components of the operation costs of the fishing boat were analyzed and identified by observation and interviewing the fishermen and shipowner. Figure 4 shows the operation cost components per year for each fishing boat size, and the fishermen's salary shows a higher cost than other cost components. As known, the fishermen's salary is influenced by the local scheme of income sharing as explained previously.

By identifying the cost components which involve the local wisdom aspect, the operational cost components of the fish recording, maintenance, fish aggregating devices (FADs), and crew salary are contributed by the value of the local wisdom whereas the costs of freshwater, ice, fuel oil, have not a contribution to the local wisdom. Figure 5 shows the weight of the local wisdom aspect of the operation costs for each fishing boat size. As the result, the weight of the local wisdom aspect contributed to the operation cost of the fishing boat $12 \mathrm{GT}, 21 \mathrm{GT}$, and 29 GT are about $63 \%, 62 \%$, and $61 \%$ respectively. Those weights show a small difference. This means that the increase of the fishing boat size exactly increases the operation cost, however, the weight of the local wisdom contribution to the operation cost is rather constant around the average of $62 \%$.

For the fishing boat investment, the weight of the local wisdom aspect on the fishing boat building and operation cost is $71.83 \%$. For this reason, the Ministry of Maritime Affairs and Fisheries (Indonesia Government) should consider the local wisdom aspect in order to succeed in the procurement assistance program for the fishing boat with its size from 5 to $30 \mathrm{GT}$.

\subsection{Business feasibility based on Net Present Value (NPV)}

For the fisheries business, Net Present Value (NPV) as a financial parameter was used to determine the feasibility of investment of the fishing boat sizes 12,21 , and 29 GT. Here, the interest rate was considered $6 \%$ by referring to Bank Rakyat Indonesia [9], and the investment period was considered ten years as equal to the ship age. As calculation results, Tables 8 to 10 show the cash flow of Net Present Value (NPV) started one year to ten years for the fishing boat sizes 12, 21, and 29 GT respectively. Based on Tables 8 to 10, the NPV is Rp. 823.182.866 for 12 GT, Rp. 998.784 .136 for 21 GT and Rp. 979.030 .777 for 29 GT. Overall NPV meets positive (>0) and this means that overall fishing boat sizes are feasible for the fisheries business that can expect a profit and should consider moving forward with the investment of the fishing boats. Moreover, overall NPV shows within the age of fishing boats can construct a new fishing boat building.

Table 8. The cash flow of the investment feasibility for the fishing boat 12 GT based on Net Present Value (NPV)

\begin{tabular}{cccc}
\hline Years & Net Income $(\mathbf{R p})$ & df 6\% & PV $(\mathbf{R p )}$ \\
\hline 0 & -150.000 .000 & 1.000 & -150.000 .0000 \\
1 & 132.224 .369 & 0.943 & 124.739 .971 \\
2 & 132.224 .369 & 0.890 & 117.679 .218 \\
3 & 132.224 .369 & 0.840 & 111.018 .130 \\
4 & 132.224 .369 & 0.792 & 104.734 .085 \\
5 & 132.224 .369 & 0.747 & 98.805 .740 \\
6 & 132.224 .369 & 0.705 & 93.212 .963 \\
7 & 132.224 .369 & 0.665 & 87.936 .757 \\
8 & 132.224 .369 & 0.627 & 82.959 .205 \\
9 & 132.224 .369 & 0.592 & 78.263 .401 \\
10 & 132.224 .369 & 0.558 & 73.833 .397 \\
\hline \multicolumn{4}{c}{ NPV } \\
\hline
\end{tabular}


Table 9. The cash flow of the investment feasibility for the fishing boat 21 GT based on Net Present Value (NPV)

\begin{tabular}{cccc}
\hline Years & Net Income $(\mathbf{R p})$ & df $6 \%$ & PV $(\mathbf{R p})$ \\
\hline 0 & -270.000 .000 & 1.000 & -270.000 .000 \\
1 & 171.028 .512 & 0.943 & 161.347 .653 \\
2 & 171.028 .512 & 0.890 & 152.214 .767 \\
3 & 171.028 .512 & 0.840 & 143.598 .837 \\
4 & 171.028 .512 & 0.792 & 135.470 .000 \\
5 & 171.028 .512 & 0.747 & 127.802 .453 \\
6 & 171.028 .512 & 0.705 & 120.568 .352 \\
7 & 171.028 .512 & 0.665 & 113.743 .729 \\
8 & 171.028 .512 & 0.627 & 107.305 .404 \\
9 & 171.028 .512 & 0.592 & 101.231 .513 \\
10 & 171.028 .512 & 0.558 & 95.501 .428 \\
\hline & & NPV & 998.784 .136 \\
\hline
\end{tabular}

Table 10. The cash flow of the investment feasibility for the fishing boat 29 GT based on Net Present Value (NPV)

\begin{tabular}{cccc}
\hline Years & Net Income/year & df 6\% & PV (Present Value) \\
\hline 0 & -400.000 .000 & 1.000 & -400.000 .000 \\
1 & 187.366 .096 & 0.943 & 176.760 .468 \\
2 & 187.366 .096 & 0.890 & 166.755 .158 \\
3 & 187.366 .096 & 0.840 & 157.316 .187 \\
4 & 187.366 .096 & 0.792 & 148.411 .497 \\
5 & 187.366 .096 & 0.747 & 140.010 .847 \\
6 & 187.366 .096 & 0.705 & 132.085 .704 \\
7 & 187.366 .096 & 0.665 & 124.609 .155 \\
8 & 187.366 .096 & 0.627 & 117.555 .807 \\
9 & 187.366 .096 & 0.592 & 110.901 .704 \\
10 & 187.366 .096 & 0.558 & 104.624 .249 \\
\hline & & NPV & 979.030 .777 \\
\hline
\end{tabular}

\subsection{Business feasibility based on Internal Rate of Return (IRR)}

Correspondingly, the fishery business was also analyzed by using the parameter of the Internal Rate of Return (IRR). Here, the IRR was used to estimate the profitability of potential investments of the fishing boats that makes the NPV of all cash flows equal to zero in a discounted cash flow analysis (NPV $=0)$. For the potential investment, Tables 11 to 13 show the cash flow based on IRR from one year to ten years for the fishing boat sizes 12,21 , and 29 GT respectively.

In this case, the overall IRR for the investment of the fishing boat $12 \mathrm{GT}, 21 \mathrm{GT}$ and $29 \mathrm{GT}$ is quite high that is $77 \%, 54 \%$, and $38 \%$ respectively. By those IRR results, three sizes of the fishing boats are the prospective investments to support the welfare of fishermen in Sinjai Regency, merely the investment with the highest IRR would probably be considered the best investments which is the fishing boat 12 GT.

Meanwhile, the fishing grounds for these fishing boats are outside the sea authority of Sinjai Regency. This will be a conflict matter for the fishermen, therefore, the fishing area in Sinjai's sea authority should be maintained and conserved for the next future and sustainability of aquaculture activities. According to White et al. [10] stated that coral reefs are a habitat for various types of fish that bring economic benefits to the wider community so that their sustainability is very important. By this effort, the operation cost will be minimized and then the income and investment will be high feasibility.
Table 11. The cash flow of the investment feasibility for the fishing boat 12 GT based on IRR

\begin{tabular}{cccc}
\hline Years & Net Income $(\mathbf{R p})$ & df 6\% & PV $(\mathbf{R p )}$ \\
\hline 0 & -150.000 .000 & 1.000 & -150.000 .0000 \\
1 & 132.224 .369 & 0.943 & 124.739 .971 \\
2 & 132.224 .369 & 0.890 & 117.679 .218 \\
3 & 132.224 .369 & 0.840 & 111.018 .130 \\
4 & 132.224 .369 & 0.792 & 104.734 .085 \\
5 & 132.224 .369 & 0.747 & 98.805 .740 \\
6 & 132.224 .369 & 0.705 & 93.212 .963 \\
7 & 132.224 .369 & 0.665 & 87.936 .757 \\
8 & 132.224 .369 & 0.627 & 82.959 .205 \\
9 & 132.224 .369 & 0.592 & 78.263 .401 \\
10 & 132.224 .369 & 0.558 & 73.833 .397 \\
\hline \multicolumn{4}{c}{ IRR } \\
\hline
\end{tabular}

Table 12. The cash flow of the investment feasibility for the fishing boat 21 GT based on IRR

\begin{tabular}{cccc}
\hline Years & Net Income $(\mathbf{R p})$ & df 6\% & PV $(\mathbf{R p )}$ \\
\hline 0 & -270.000 .000 & 1.000 & -270.000 .000 \\
1 & 171.028 .512 & 0.943 & 161.347 .653 \\
2 & 171.028 .512 & 0.890 & 152.214 .767 \\
3 & 171.028 .512 & 0.840 & 143.598 .837 \\
4 & 171.028 .512 & 0.792 & 135.470 .000 \\
5 & 171.028 .512 & 0.747 & 127.802 .453 \\
6 & 171.028 .512 & 0.705 & 120.568 .352 \\
7 & 171.028 .512 & 0.665 & 113.743 .729 \\
8 & 171.028 .512 & 0.627 & 107.305 .404 \\
9 & 171.028 .512 & 0.592 & 101.231 .513 \\
10 & 171.028 .512 & 0.558 & 95.501 .428 \\
\hline & & IRR & $54 \%$ \\
\hline
\end{tabular}

Table 13. The cash flow of the investment feasibility for the fishing boat 29 GT based on IRR.

\begin{tabular}{cccc}
\hline Years & Net Income (Rp) & df 6\% & PV (Rp) \\
\hline 0 & -400.000 .000 & 1.000 & -400.000 .0000 \\
1 & 187.366 .096 & 0.943 & 176.760 .468 \\
2 & 171.028 .512 & 0.890 & 166.755 .158 \\
3 & 171.028 .512 & 0.840 & 157.316 .187 \\
4 & 171.028 .512 & 0.792 & 148.411 .497 \\
5 & 171.028 .512 & 0.747 & 140.010 .847 \\
6 & 171.028 .512 & 0.705 & 132.085 .704 \\
7 & 171.028 .512 & 0.665 & 124.609 .155 \\
8 & 171.028 .512 & 0.627 & 117.555 .807 \\
9 & 171.028 .512 & 0.592 & 110.901 .704 \\
10 & 171.028 .512 & 0.558 & 104.624 .249 \\
\hline \multicolumn{5}{r}{} & IRR & $38 \%$ \\
\hline
\end{tabular}

\section{Conclusion}

The study on the investment feasibility of the fishing boats 12 GT, 21 GT, and 29 GT considering the local wisdom aspect in Sinjai Regency was carried out successfully. The weight of the local wisdom aspect and investment feasibility of fishing boats based on NPV and IRR are obtained accordingly.

By using the sharing factor based on the local scheme, shipowner based on the fishing boat size 12 GT, 21 GT, and 29 GT gains the income of Rp. 132.224.369, Rp. 179.677.821, and Rp. 187.366.096, respectively. These ownership incomes are used to analyze investment feasibility for those kinds of fishing boats following.

The weight of the local wisdom involved in the shipbuilding cost for the fishing boat sizes of $12 \mathrm{GT}, 21$ GT, and 29 GT are approximately $83 \%, 79 \%$, and $83 \%$ respectively. The high weight of the involvement of local wisdom aspects in the fishing boat building is contributed by the hull form including bow shape, type of fishing gear, 
room layout, and steering system. In addition, the weight of the local wisdom aspect contributed to the operation cost of the fishing boat $12 \mathrm{GT}, 21 \mathrm{GT}$, and $29 \mathrm{GT}$ are about $63 \%, 62 \%$, and $61 \%$ respectively. Therefore, For the fishing boat investment, the overall weight of the local wisdom aspect on the fishing boat building and operation cost is $71.83 \%$. As the high local wisdom aspect involved in the investment of fishing boats, the Ministry of Maritime Affairs and Fisheries (Indonesia Government) should consider it in order to succeed in the procurement assistance program.

Moreover, the NPV within ten years (the age of fishing boat) with the interest rate of $6 \%$ is Rp. 823.182.866 for 12 GT, Rp. 998.784.136 for 21 GT and Rp. 979.030.777 for 29 GT. Overall NPV meet positive (>0). In addition, the overall IRR for the investment of the fishing boat 12 GT, $21 \mathrm{GT}$, and $29 \mathrm{GT}$ are quite high that is $77 \%$, 54\%, and $38 \%$ respectively. Based on those results of NPV and IRR, the fisheries business can expect a profit and should consider moving forward with the investment of the fishing boats. Then, three sizes of the fishing boats are the prospective investments to support the welfare of fishermen in Sinjai Regency.

\section{Acknowledgements}

We are grateful to the head of the fish auction in Sinjai Regency, fishing boat owners, and crew members for their kind help during this research that was carried out.

\section{References}

[1] Praharsi Y, Jami'in MA, Suhardjito G, Wee HM. Modeling a traditional fishing boat building in East Java, Indonesia. Ocean Eng. 2019; 189:106234.
[2] Santoso AW, Novita Y, Iskandar BH, Baskoro MS. Fishing boat design based local wisdom in Southeast Sulawesi fishermen. American Journal of Software Engineering and Applications, 2020; 9(1):1-18.

[3] Supomo H, Baihaqi L, Pribad TW, Wahidi SI. Design for production and operation for traditional fishing boat based on local wisdom. Marine Techonolgy for Sustainable Development, 2017; II:166172.

[4] Rinaldi AC, Adhawati SS, Mallawa A. Feasibility of pole-and-line fishery: comparison of milkfish (chanoschanos, forskal) and anchovy (stolephorussp) as Live Bait. Int. J. Environ. Agric. Biotechnol, 2019; 4(5):567-1572.

[5] Pribadi SRW, Ariesta RC, Puspitasari HP. Financial feasibility analysis of wooden fishing vessel in Panggungrejo. Economic and Social of Fisheries and Marine Journal, 2019; 6(2):149-157.

[6] Tidd AN, Hutton T, Kell LT, Padda G. Exit and entry of fishing vessels: an evaluation of factors affecting investment decisions in the North Sea English beam trawl fleet. ICES J. Mar. Sci., 2011; 68(5):961-971.

[7] Rosdianto. Financial Analysis of fishing boat rental business at Kenyamukan Hamlet, District of North Sangatta, Regency of East Kutai, Sumatra. Journal of Disaster, Geography and Geography Education, 2017; 1(1):68-77.

[7] Purba R. Analisis biaya dan manfaat (cost and benefit analysis), Rineka Putra: Jakarta;1997.

[8] Republik Indonesia, Undang-Undang (UU) Nomor 16 Tahun 1964, tentang bagi hasil perikanan, Pemerintah Pusat. Jakarta.

[9] Kur.bri.co.id. Kredit Usaha Rakyat Bank Rakyat Indonesia, retrieved at https://kur.bri.co.id/, August 20, 2020.

[10] White AL, Hale LZ, Renard Y, Cortesi L. Collaborative and community-based management of coral reef: lessons from experience. Kumarian Press, Inc., West Hartford, Connecticut;1994. 